the USA and other countries. Research by the David Rockefeller Studies Program centres on major geopolitical areas but also covers global health, international institutions and global governance, national security, science and technology and US foreign policy. Sister organization of Chatham House in London.

Address: The Harold Pratt House, 58 East 68th St., New York, NY 10065, USA.

Website: http://www.cfr.org

Board of Directors Chairs: Carla A. Hills; Robert E. Rubin.

President: Richard N. Haass.

\section{Danish Institute for International Studies}

Founded 2002 by the Danish parliament. Independent institution engaged in research in international affairs in order to assess the security and foreign policy situation of Denmark. Research units: defence and security; foreign policy and EU studies; global economy, regulation and development; holocaust and genocide; migration; natural resources and poverty; politics and governance; the Middle East.

Address: Østbanegade 117, 2100 Copenhagen, Denmark.

Website: http://www.diis.dk

Director: Nanna Hvidt.

\section{European Council on Foreign Relations}

Founded 2007. Pan-European think tank that conducts European foreign policy research and promotes a more integrated European foreign policy in support of shared European interests and values. Main programmes: Russia and wider Europe; China; democracy, human rights and the rule of law.

Address: 35 Old Queen St., London SW1H 9JA, UK.

Website: http://www.ecfr.eu

Director: Mark Leonard.

\section{Fraser Institute}

Founded 1974. Independent non-partisan research and educational organization that aims to measure, study and communicate the impact of competitive markets and government interventions on the welfare of individuals. Research covers taxation, government spending, health care, school performance and trade.

Address: 4th Floor, 1770 Burrard St., Vancouver, BC, Canada

V6J 3 G7.

Website: http://www.fraserinstitute.org

President: Niels Veldhuis.

\section{French Institute of International Relations (IFRI)}

Founded 1979. The Institut Français des Relations Internationales is an independent research and debate institution dedicated to international affairs. Research centres on geographic regions as well as economy; energy; Franco-German relations; health/ environment; migration; identities and citizenship; security and defence; space; and sport.

Address: 27 rue de la Procession, 75740 Paris Cedex 15, France. Website: http://www.ifri.org

Secretary-General: Valérie Genin.

\section{Friedrich Ebert Foundation (Friedrich-Ebert-Stiftung; FES)}

Founded in 1925 as a political legacy of Germany's first democratically elected president, Friedrich Ebert. Non-profit foundation committed to the advancement of public policy issues in the spirit of the basic values of social democracy. Focuses on democracy promotion and international dialogue on the central topics of international politics, globalization, and economic, social and political development in the world.

Address: Berliner Haus, Hiroshimastrasse 17, 10785 Berlin, Germany; Bonner Haus, Godesberger Allee 149, 53175 Bonn, Germany.

Website (German only): http://www.fes.de

Chairman: Kurt Beck.

\section{Fundação Getulio Vargas}

Founded 1944. Higher education establishment dedicated to social sciences research to develop the socio-economic position of Brazil. Research covers business, citizenship, education, finance, justice, health, history, law, macro and microeconomics, politics, pollution, poverty and unemployment, sustainable development and welfare.

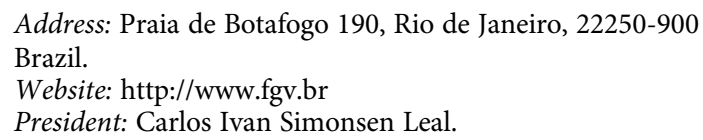

\section{German Council on Foreign Relations}

Founded 1945. Independent, non-partisan and non-profit membership organization and think tank that promotes public debate on foreign policy. Research programmes focus on: China; energy policy; European integration; global economics; international security policy; Middle East; Russia/Eurasia; transatlantic relations.

\author{
Address: Rauchstrasse 17-18, 10787 Berlin, Germany. \\ Website: https://dgap.org \\ President: Arend Oetker.
}

\section{German Institute for International and Security Affairs (Stiftung Wissenschaft und Politik; SWP)}

Founded 1962. Independent scientific establishment that conducts practically oriented research on the basis of which it then advises the Bundestag and the German federal government on foreign and security policy issues. Research divisions: EU integration; EU external relations; international security; the Americas; Russian Federation/CIS; Middle East and Africa; Asia; global issues.

Address: Ludwigkirchplatz 3-4, 10719 Berlin, Germany.

Website: http://www.swp-berlin.org

Director: Prof. Dr Volker Perthes.

\section{Heritage Foundation}

Founded 1973. Conservative think tank aiming to formulate and promote public policies based on the principles of free enterprise, limited government, individual freedom, traditional American values and a strong national defence. Target audience includes members of Congress, key congressional staff members, policymakers in the executive branch, the news media, and the academic and public policy communities.

Address: 214 Massachusetts Ave., NE, Washington, D.C., 20002-4999, USA.

Website: http://www.heritage.org

President: Jim DeMint. 